\title{
UNJUK KERJA REAKTOR PLASMA DIELECTRIC BARRIER DISCHARGE UNTUK PRODUKSI BIODIESEL DARI MINYAK KELAPA SAWIT
}

\author{
Ardian Dwi Yudhistira *), I. Istadi **)
}

\begin{abstract}
Biodiesel is one of alternative renewable energy source to substitute diesel fuel. Various biodiesel production processes through transesterification reaction with a variety of catalysts have been developed by previous researcher. This process still has the disadvantage of a long reaction time, and high energy need. Dielectric Barrier Discharge (DBD) plasma electro-catalysis may become a solution to overcome the drawbacks in the conventional transesterification process. This process only needs a short time reaction and low energy process. The purpose of this study was to assess the performance of DBD plasma rector in making biodiesel such as: the effect of high voltage electric value, electrodes gap, mole ratio of methanol / oil, and reaction time. The Research method was using GC-MS (Gas Cromatography-Mass Spectrofotometry) and FTIR (Fourier Transform Infrared Spectrofotometry) and then it will be analysed the change of chemical bond between reactant and product. So, the reaction mechanism can be predicted. Biodiesel is produced using methanol and palm oil as reactants and DBD plasma used as reactor in batch system. Then, reactants contacted by high voltage electric. From the results of this research can be concluded that the reaction mechanism occurs in the process is the reaction mechanism of cracking, the higher of electric voltage and the longer of reaction time lead to increasing of product yield. The more of mole ratio of methanol / oil and widening the gap between the electrodes lead to decreased product yield. From this research, product yield maksimum is $89,8 \%$ in the variable of rasio mol metanol/palm oil 3:1, voltage $10 \mathrm{kV}$, electrode gap 1,5 cm, and reaction time 30 seconds.

Key words: Biodiese; Plasma; Electro-catalysis; Dielectric Barrier Dischrage (DBD)
\end{abstract}

\section{Pendahuluan}

Substitusi energi fosil dengan energi terbarukan sudah banyak diteliti. Saat ini bahan bakar alternatif yang potensial di aplikasikan di Indonesia untuk mensuplai kebutuhan bahan bakar menggantikan solar adalah biodiesel. Hal ini dikarenakan melimpahnya bahan baku pembuatan biodiesel yang tersedia di Indonesia (Joelianingsih et al., 2012). Biodiesel juga banyak digunakan sebagai bahan bakar alternatif di negara lain terbukti permintaan akan biodiesel terus meningkat sejak tahun 2005 terutama di Amerika serikat (Juan et al., 2011). Terdapat beberapa kelebihan biodiesel dibanding bahan bakar diesel konvensional yaitu penggunaan biodiesel dapat membantu mengurangi polusi karbon dioksida serta polutan lain, modifikasi mesin tidak diperlukan dalam penggunaan biodiesel sebagai bahan bakar, merupakan bahan bakar yang dapat diperbarui, performa biodiesel lebih baik karena angka cetana yang lebih tinggi, biodisel dengan kemurnian tinggi tidak memerlukan penggunaan pelumas, produksi biodiesel lebih efisien karena tidak memerlukan pengeboran lepas pantai, dan terciptanya kemandirian energi di setiap daerah karena dapat memproduksi sendiri (Juan et al., 2011).

Berbagai cara atau metode pembuatan biodiesel banyak dikembangkan antara lain yang paling banyak digunakan adalah dengan metode konvensional (dengan katalis homogen). Kelemahan terbesar dalam penggunaan katalis homogen adalah dapat terbentuknya reaksi penyabunan akibat reaksi gugus $\mathrm{OH}$ pada katalis dengan bahan baku minyak yang mengandung FFA dengan kadar tinggi. Terbentuknya sabun selain

\footnotetext{
*) Mahasiswa Magister T. Kimia FT Undip

**) Staf Pengajar Jurusan Teknik Kimia FT Undip
}

dapat mengurangi konversi reaksi, juga dapat menyulitkan dalam proses pemisahan produk dan katalis tidak dapat diregenerasi kembali (Juan et al., 2011). Pengembangan lebih lanjut metode konvensional banyak dilakukan dengan mengganti penggunaan katalis homogen dengan katalis heterogen. Dengan menggunakan katalis heterogen dapat menghemat waktu dan biaya dalam proses pemisahan di akhir proses tetapi memiliki konversi reaksi yang lebih rendah (Juan et al., 2011). Metode konvensional dengan katalis homogen dan heterogen ini memiliki kendala yang cukup signifikan yaitu adanya pembentukan senyawa gliserol dalam jumlah yang cukup besar, membutuhkan energi yang cukup besar untuk proses pemanasan, membutuhkan waktu reaksi yang lama kurang lebih 1-8 jam, serta di akhir proses memerlukan biaya lebih dan waktu yang lama sekitar 8-16 jam untuk proses pemisahan dan pemurnian (Lawson \& Baosman, 2010a, 2010b).

Selain metode konvensional yang telah dijelaskan di atas, terdapat metode lain yang telah dikembangkan dalam produksi biodiesel antara lain menggunakan radiasi gelombang ultrasonic dan microwave. Metode ultrasonic membutuhkan waktu reaksi yang masih cukup lama sekitar 30 menit, masih terbentuk senyawa gliserol, serta membutuhkan katalis basa homogen (Babajide et al., 2010), sedangkan metode radiasi microwave membutuhkan waktu reaksi sekitar 5-60 menit, membutuhkan metanol berlebih yang lebih banyak (sekitar 1:8 (mol minyak : metanol)), menghasilkan gliserol sebagai reaksi samping dan masih membutuhkan katalis basa homogen (Azcan et al., 2013; Gude et al., 2013). 
Sistem elektro-katalisis di dalam penelitian ini dimaksudkan sebagai pemanfaatan elektron berenergi tinggi sebagai katalis dalam reaksi pembentukan biodiesel. Elektron berenergi tinggi ini diduga dapat bertindak sebagai katalis sebagaimana pada proses katalitik konvensional. Aplikasi teknologi elektro-katalisis dalam pembuatan biodiesel dapat dikerjakan pada temperatur ruangan dan tekanan atmosferik karena sifat plasma dalam reaksi adalah non-equilibrium plasma atau non-thermal plasma dimana terdapat perbedaan suhu yang signifikan antara elektron-elektron dan partikel-partikel netral. (Caldwell et al., 2001; Istadi \& Amin, 2006; Elliason \& Kogelschazt, 1991)

Dalam proses ini minyak tumbu-han dan metanol dikontakkan dengan elektron bere-nergi tinggi untuk menghasilkan mono alkil ester. Yield produk dapat mencapai hampir $100 \%$, tanpa ada reaksi pembentukan sabun dan gliserol, sehingga tidak memerlukan pemisahan kontaminan pada akhir proses. Yang lebih menarik lagi adalah waktu reak-sinya menjadi lebih singkat sehingga waktu total untuk reaksi dapat ditekan seminimal mungkin (bah-kan hanya beberapa detik).

Terlepas dari semua kelebihan yang sudah disebutkan di atas, pengembangan teknologi elektro-katalisis untuk produksi biodiesel memiliki masalah krusial yaitu pada desain reaktor plasma. Disain dan kon-figurasi reaktor plasma menjadi kunci penting karena keberhasilan sintesis sangat ditentukan oleh efektifitas kontak antara elektron berenergi tinggi dan campuran minyak dan metanol yang berlangsung di dalam reaktor plasma. Lama waktu kontak elektron dan reaktan juga merupakan merupakan parameter penting karena sangat menentukan menjadi senyawa apa yang akan dihasilkan oleh proses tersebut. Reaktor plasma jenis Dielectric Barier Discharge dapat menjamin tidak ada spark atau arc di dalam ruang discas. Reaktor jenis ini juga sangat potensial untuk reaksi-reaksi kimia organik maupun anorganik karena sifatnya yang non-equilibrium (Istadi, 2006). Sehingga pengembangan reaktor plasma jenis DBD untuk produksi biodiesel perlu untuk diteliti lebih lanjut.

Produk yang dihasilkan tidak mengandung gliserol dan sabun, dan tidak memerlukan tambahan katalis karena dalam proses ini elektron berenergi tinggi digunakandi dalam reaktor plasma untuk menggantikan peran katalis. Hingga sekarang, hanya beberapa peneliti saja yang fokus kepada mmetode elektrokatalisis untuk produksi biodiesel (Lawson \& Baosman, 2010a, 2010b). Namun demikian, mereka belum mengkaji secara mendalam tentang parameterparameter yang berpengaruh dalam reaksi elektrokatalisis menghasilkan biodiesel. Oleh karena itu, penelitian produksi biodiesel menggunakan proses elektro-katalisis tegangan tinggi memerlukan penelitian yang lebih lanjut dan mendalam, terutama pencarian informasi tentang parameter-parameter yang mempengaruhi kinerja proses elektro-katalisis dalam memproduksi biodiesel.

Tujuan penelitian ini adalah untuk mengkaji kinerja reaktor plasma DBD dalam pembuatan biodiesel. Kajian tersebut meliputi pengaruh-pengaruh parameter seperti: besar voltase tegangan tinggi, jarak antar elektroda, perbandingan mol metanol/minyak dan waktu reaksi.

\section{Bahan dan Metode Penelitian}

Bahan dan Alat

Bahan-bahan yang digunakan dalam penelitian ini antara lain minyak kelapa sawit komersial (Tropicana 2x penyaringan) dan metanol (Merck, 99.9\%) sebagai bahan utama pembuatan biodiesel. Reaksi pembentukan biodiesel dilakukan di dalam reaktor plasma jenis Dielectric Barier Discharge. Reaktor dirancang untuk sistem batch berupa Erlenmeyer $250 \mathrm{ml}$ yang dilapisi gipsum sebagai bahan isolator dengan bagian alas tidak dilapisi isolator. Elektroda tegangan tinggi terbuat dari tembaga, sedangkan elektroda ground terbuat dari stainless steel. Sebagai penyedia tegangan tinggi digunakan alat High Voltage Power Supply dengan power hingga 330 Watt, serta High Voltage Probe (SEW PD-28 High Voltage Probe) dan multimeter (Sanwa) digunakan sebagai pengukur tegangan listrik saat reaksi berlangsung. GC-MS (Gas Cromatography-Mass Spectrometri) dengan tipe alat QP2010S SHIMADZU (analisa sampel menggunakan kolom DB-1 dengan suhu oven $80^{\circ} \mathrm{C}$ (5 menit) dinaikkan $10^{\circ} \mathrm{C} /$ menit hingga suhu $300^{\circ} \mathrm{C}$ dan ditahan selama 33 menit) digunakan dalam analisa produk. Rangkaian alat penelitian terlihat pada Gambar 1.

\section{Variabel Penelitian}

Parameter yang ditetapkan antara lain: tekanan atmosferik, suhu reaksi $60-65^{\circ} \mathrm{C}$, basis volume campuran metanol dan minyak $50 \mathrm{ml}$, sedangkan variabel bebasnya antara lain: waktu reaksi 30 detik, 2 menit, 5 menit; rasio mol metanol/minyak $3: 1$; 6:1; 9:1; Voltase $6,8,10 \mathrm{kV}$; dan jarak elektroda dengan ground 1,$5 ; 2,5 ; 3,5 \mathrm{~cm}$. Kinerja proses elektrokatalisis minyak dan metanol menjadi dapat diketahui melalui pengujian dengan memvariasikan variabel bebas perbandingan mol metanol/minyak, voltase tegangan tinggi, jarak antar elektoda dan waktu reaksi. Rancangan variasi variabel bebas disajikan di Tabel 1.

Untuk menghitung besarnya yield produk menggunakan Persamaan 1.

\begin{tabular}{l}
$\%$ Yield $=$ Massa Produk tanpa metanol sisa x $100 \%$ \\
\cline { 2 - 2 } produk
\end{tabular}

Pembuatan Biodiesel

Di Dalam Reaktor Plasma DBD

Sintesa biodiesel pada penelitian ini dimulai dengan mencampurkan metanol/minyak dengan rasio mol sesuai Tabel 1 ke dalam reaktor dengan basis volume campuran $50 \mathrm{ml}$. Sebelumnya reaktor telah dibebaskan dari adanya udara dengan mengalirkan gas 


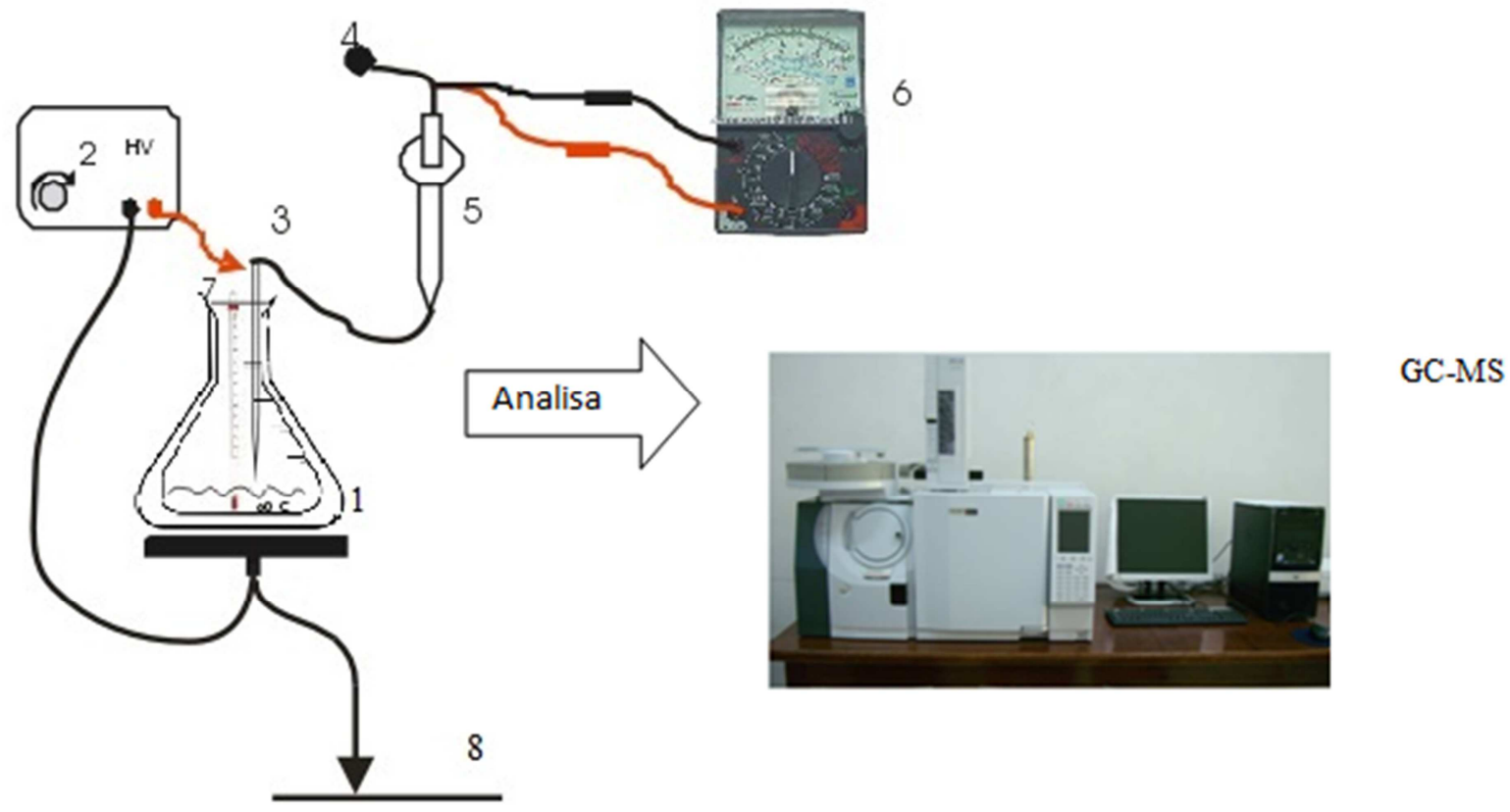

Gambar 1. Rangkaian Alat Penelitian (1) erlenmeyer yang dilapisi gypsum, (2) high voltage power supply, (3) elektroda tegangan tinggi terbuat dari tembaga, (4) elektoda ground terbuat dari stainless steel, (5) High Voltage Probe, (6) multimeter, (7) termometer, (8) ground tanah, dan (9) ground tanah untuk alat High Voltage Probe

Tabel 1. Rancangan Penelitian Performa Reaksi Elektro-Katalisis (tekanan $=1 \mathrm{~atm}, \mathrm{suhu}=60-65^{\circ} \mathrm{C}$ )

\begin{tabular}{|c|c|c|c|c|c|c|c|c|c|c|}
\hline \multirow[b]{2}{*}{$\begin{array}{l}\text { Run } \\
\text { ke- }\end{array}$} & \multicolumn{3}{|c|}{ Variabel Bebas } & & \multicolumn{5}{|c|}{ Analisa Hasil Biodiesel } & \multirow[b]{2}{*}{$\begin{array}{c}\text { Yield } \\
\text { Produk } \\
(\%)\end{array}$} \\
\hline & $\begin{array}{c}\text { Rasio Mol } \\
\text { Metanol : } \\
\text { Minyak }\end{array}$ & $\begin{array}{c}\text { Besar } \\
\text { Voltase } \\
(\mathrm{kV})\end{array}$ & $\begin{array}{c}\text { Jarak antar } \\
\text { Elektroda } \\
(\mathrm{cm})\end{array}$ & \begin{tabular}{|l|} 
Waktu \\
reaksi \\
(detik)
\end{tabular} & $\begin{array}{l}\text { Densitas \& } \\
\text { Viskositas }\end{array}$ & FAME & $\begin{array}{c}\text { Angka } \\
\text { Asam }\end{array}$ & $\begin{array}{l}\text { Angka } \\
\text { Setana }\end{array}$ & $\begin{array}{l}\text { Kalor } \\
\text { Bakar }\end{array}$ & \\
\hline 1 & $6: 1$ & 10 & 1,5 & 30 & \multirow{8}{*}{ 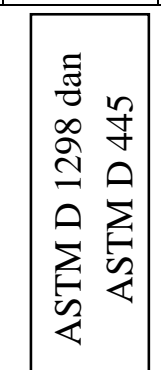 } & \multirow{8}{*}{ 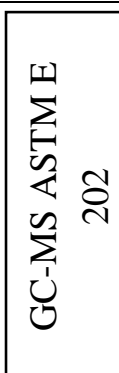 } & \multirow{9}{*}{ 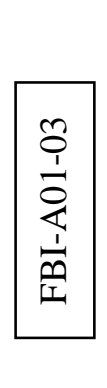 } & \multirow{8}{*}{ 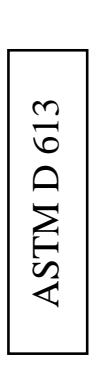 } & \multirow{9}{*}{ 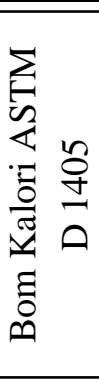 } & - \\
\hline 2 & $6: 1$ & 10 & 1,5 & 120 & & & & & & - \\
\hline 3 & $6: 1$ & 10 & 1,5 & 300 & & & & & & - \\
\hline 4 & $6: 1$ & 6 & 1,5 & 120 & & & & & & - \\
\hline 5 & $6: 1$ & 8 & 1,5 & 120 & & & & & & - \\
\hline 6 & $3: 1$ & 10 & 1,5 & 120 & & & & & & - \\
\hline 7 & $9: 1$ & 10 & 1,5 & 120 & & & & & & - \\
\hline 8 & $6: 1$ & 10 & 2,5 & 120 & & & & & & - \\
\hline 9 & $6: 1$ & 10 & 3,5 & 120 & & & & & & - \\
\hline
\end{tabular}

nitrogen ke dalam reaktor selama 2 menit hingga semua udara dapat dikeluarkan dari reaktor. Udara dihilangkan dengan tujuan untuk menghindari terjadinya reaksi oksidasi oleh gas $\mathrm{O}_{2}$. Penggunaan gas nitrogen dikarenakan sifatnya yang inert, mempu-nyai voltase breakdown yang relatif rendah dan jumlahnya yang banyak (Lindner \& Besser, 2012). Setelah reaktor bebas udara, campuran reaktan methanol / minyak dengan perbandingan sesuai Tabel 1 (mol 3:1, 6:1, dan 9:1) dimasukkan, kemudian dipanaskan dan diaduk sampai suhu $65^{\circ} \mathrm{C}$ selama 30 menit. Tinggi cairan reaktan dijaga $1 \mathrm{~cm}$ dan tidak menempel ujung elektroda. Reaktor kemudian dipasangkan pada rangkaian seperti pada Gambar 1. Jarak elektroda tegangan tinggi dengan elektroda ground diatur sesuai Tabel 1 $(1,5 ; 2,5$; dan $3,5 \mathrm{~cm})$. Setelah itu, voltase listrik diatur sesuai Tabel $1(6,8$, dan $10 \mathrm{kV})$ dengan waktu kontak diatur sesuai Tabel 1 (30, 120, 300 detik). Campuran produk ditampung dan metanol sisa dipisahkan. Pro- duk yang bebas metanol dianalisa menggunakan Gas Chromatography-Mass Spectro-metry (GC-MS) dan analisa lainnya seperti: analisa viskositas, densitas, angka asam, angka setana, kalor panas, dan yield produk.

\section{Hasil dan Pembahasan}

Proses elektro-katalisis untuk reaksi antara minyak dan metanol menghasilkan biodiesel dilakukan di dalam reaktor plasma jenis Dielectric Barrier Dis-charge. Dalam reaktor plasma ini, elektron berenergi tinggi yang dihasilkan dari alat high voltage power supply digunakan sebagai sumber energi untuk reaksi. Plasma terdiri dari elektron, ion, radikal bebas, atom dan molekul yang tereksitasi, photon dan partikel netral memiliki energi yang tinggi. Senyawa-senyawa yang terdapat di dalam plasma membantu proses reaksi elektro-katalisis. Suhu elektron yang terakse-lerasi oleh medan listrik yang kuat dapat mencapai 10.000 
$\mathrm{K}$, sedangkan suhu medium hanya sebesar suhu ruangan (Istadi, 2006; Rahimpour et al., 2013). Dalam suatu reaksi, plasma sangat sensitif dengan adanya sekumpulan spesies aktif, oleh karena itu mekanisme reaksi plasma sangat sulit untuk diprediksi (Rahimpour et al., 2013).

\section{Pengaruh Besarnya Tegangan Listrik}

Tegangan listrik yang diaplikasikan dalam penelitian ini ditentukan pada kisaran 6,8 , dan $10 \mathrm{kV}$. Untuk aplikasi tegangan listrik di atas $10 \mathrm{kV}$ tidak dapat dilakukan karena keterbatasan alat high voltage power supply. Hasil penelitian tentang pengaruh besarnya tegangan dapat dilihat di Gambar 2.

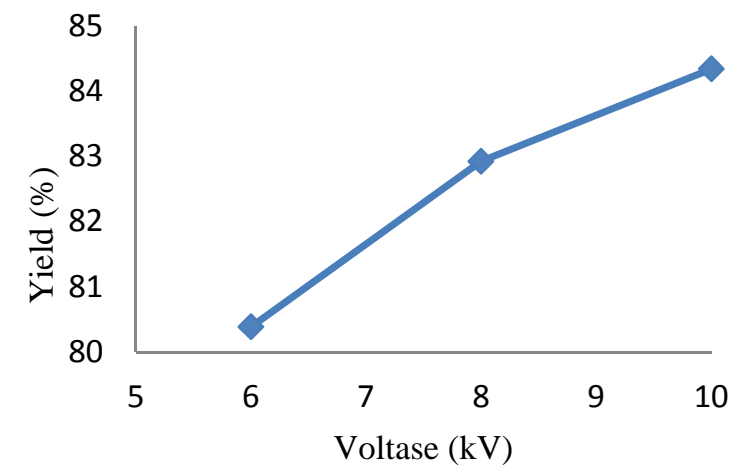

Gambar 2. Pengaruh besar voltase tegangan tinggi terhadap yield produk yang dihasilkan

Dari Gambar 2, dapat diketahui bahwa semakin besar voltase listrik yang diaplikasikan di dalam proses elektro-katalisis maka yield produk yang dihasilkan akan semakin besar. Tegangan yang tinggi mengakibatkan densitas arus micro-discharge yang dihasilkan meningkat dan semakin kuat. Oleh karena itu, semakin besar voltase listrik membuat energi elektron dan ion yang dihasilkan semakin besar. Fenomena ini sesuai dengan hail penelitian sebelumnya (Jahanmiri et.al., 2012; Rahimpour et.al., 2013). Hal ini menyebabkan semakin besar kemungkinan terjadi tumbukan antara elektron dan ion dengan reaktan didalam zona plasma. Tumbukan yang terjadi menga-kibatkan ikatan kimia rantai minyak dan metanol terputus menjadi senyawa-senyawa yang lebih pendek (Jahanmiri et al., 2012; Rahimpour et al., 2013). Yield produk didapat dari Persamaan 1.

\section{Pengaruh Jarak Antar Elektroda}

Salah satu keuntungan dari reaktor plasma DBD adalah memunginkan untuk merubah energi rata-rata elektron dengan mengubah lebar jarak antara elektroda tegangan tinggi dengan elektroda ground (Istadi \& Amin, 2006; Taghvaei et al., 2012). Dari penelitian sebelumnya, semakin pendek jarak antar elektroda maka semakin stabil proses operasinya (Moscosa et al., 2008).

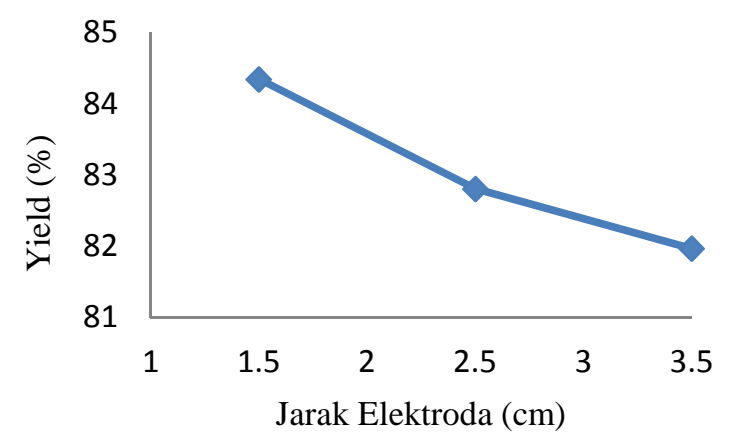

Gambar 3. Pengaruh jarak elektroda terhadap yield produk yang dihasilkan

Data hasil penelitian pengaruh jarak elektroda dengan ground tersaji dalam Gambar 3. Dari hasil ini dapat diketahui bahwa semakin lebar jarak antar elektroda maka yield produk yang dihasilkan menurun. Fenomena ini sesuai dengan hasil penelitian sebelumnya (Ndong et al., 2013; Taghvaei et al., 2012). Hal ini dikarenakan semakin lebar jarak antar elektroda, medan listrik (volt/cm) yang dihasilkan semakin kecil, sehingga energi elektron rata-rata yang dihasilkan lebih kecil. Semakin kecil energi elektron yang digunakan maka semakin kecil rantai yang dapat terputus yang mengakibatkan yield produk yang dihasilkan semakin turun (Ndong et al., 2013; Taghvaei et al., 2012).

\section{Pengaruh Perbandingan Mol Metanol/Minyak}

Perbandingan mol metanol/minyak yang digunakan pada penelitian ini adalah $3: 1 ; 6: 1$; dan 9:1. Hasil penelitian mengenai pengaruh perbandingan mol metanol/minyak dapat dilihat di Gambar 4. Dari Gambar 4, dapat diketahui bahwa semakin besar perbandingan mol metanol/minyak maka yield produk yang dihasilkan semakin kecil. Hal ini dikarenakan energi elektron yang digunakan untuk reaksi banyak terpakai untuk memecah ikatan metanol yang berlebih karena energi ikatan rata-rata metanol lebih kecil di bandingkan ikatan minyak sehingga energi untuk me-mecah ikatan minyak berkurang yang mengakibatkan yield yang dihasilkan menurun.

Metanol berfungsi sebagai penghasil radikal bebas $\mathrm{H}^{*}$ dan $\mathrm{OH}^{*}$ yang banyak bereaksi dengan minyak. Jumlah metanol yang terlalu banyak akan mengurangi energi untuk memecah ikatan minyak menjadi senyawa metil ester. 


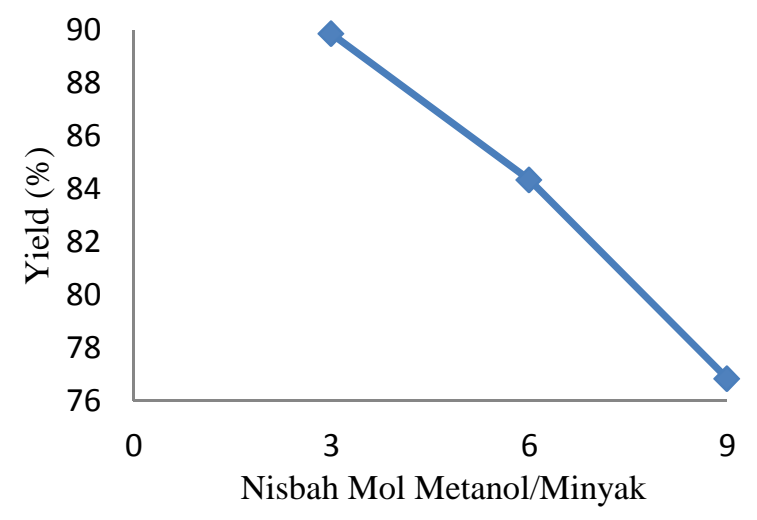

Gambar 4. Pengaruh perbandingan mol metanol/minyak terhadap yield produk yang dihasilkan

\section{Pengaruh Lamanya Waktu Reaksi}

Waktu reaksi yang lebih lama tentu akan meyebabkan efisiensi energi reaksi yang lebih rendah. Apalagi bila proses tersebut menggunakan plasma yang mempunyai energi yang sangat tinggi. Waktu reaksi yang lebih lama tentu akan meyebabkan efisiensi energi reaksi dalam reaktor plasma menjadi lebih rendah. Energi efisiensi mencerminkan efisiensi dalam mengubah energi listrik menjadi energi kimia yang tersimpan dalam produk dalam bentuk senyawasenyawa dengan rantai yang lebih pendek (Istadi, 2006). Dalam proses elektro-katalisis dengan tegangan tinggi, waktu reaksi menjadi sangat penting mengingat plasma dapat memutus ikatan yang tidak diinginkan dan mengakibatkan reaksi berantai.

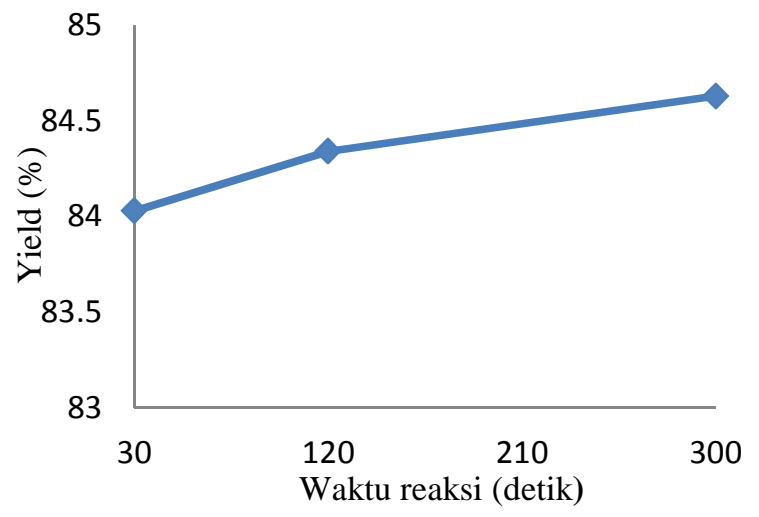

Gambar 5. Pengaruh waktu reaksi terhadap yield produk yang dihasilkan

Dari hasil penelitian yang disajikan pada Gambar 5, dapat diketahui bahwa semakin lama waktu reaksi menyebabkan yield produk yang dihasilkan menjadi semakin banyak. Fenomena ini sesuai dengan penelitian sebelumnya (Rahimpour et al., 2013). Hal ini dikarenakan efisien energi yang semakin besar menyebabkan terjadinya reaksi pemutusan rantai menjadi rantai yang lebih pendek semakin banyak.

\section{Karakterisasi Produk Biodiesel}

Dari hasil uji GCMS, secara garis besar reaksi antara metanol dan minyak dengan bantuan elektro-katalisis membentuk senyawa antara lain metil ester (FAME), aldehid, alkuna, alkohol, ester, dan asam karboksilat. Kromatogram GC-MS untuk produksi biodiesel disajikan di Gambar 6, sedangkan identifikasi senyawasenyawa yang terdeteksi disajikan di Tabel 2.

Dari Tabel 2, pada waktu reaksi 120 detik, senyawa FAME (Fatty Acid Methyl Ester) terdapat pada peak $2,3,4,5,7$. Senyawa lain yang terbentuk pada waktu reaksi 120 detik antara lain: 1-heptyne (alkuna) pada peak 1, isooctanol (alkohol) pada peak 6, 9-hexadecenoic acid (asam karboksilat) pada peak 8, octadecanal (aldehid) pada peak 9 dan 9-octadecenal (aldehid) pada peak 10 .

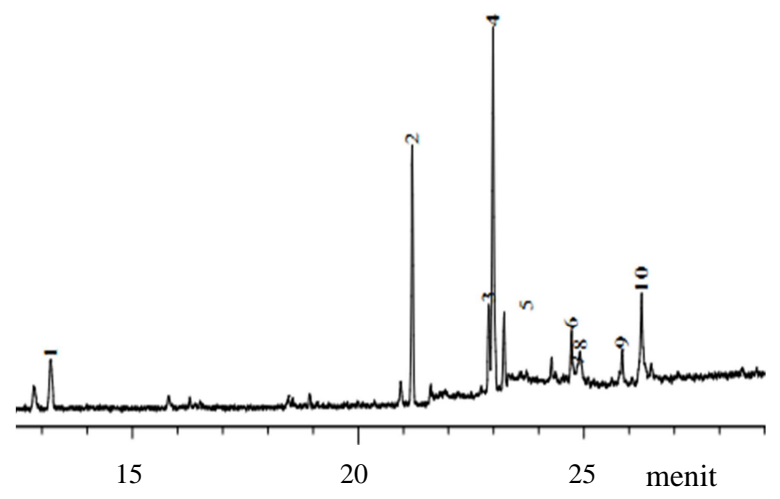

Gambar 6. Kromatogram identifikasi komponen Fatty Acid Methyl Ester (FAME) dengan GC-MS dengan waktu reaksi 120 detik.

Dari Gambar 6 (waktu reaksi 120 detik), puncak tertinggi dihasilkan pada peak 4 yang merupakan senyawa 11-octadecenoic acid methyl ester dengan waktu retensi 22,987 menit.

Terbentuknya senyawa-senyawa lain selain FAME diduga berasal dari reaksi antara radikal bebas-radikal bebas yang terbentuk karena pemutusan rantai ikatan senyawa minyak dan metanol yang tidak beraturan. Proses elektro-katalisis minyak dan metanol menggunakan elektron berenergi tinggi yang berasal dari energi listrik sebagai sumber energi reaksi. Elektronelektron berenergi tinggi bertumbukan dengan senyawa minyak dan metanol yang dapat memutus rantai ikatan keduanya menjadi senyawa ion, radikal bebas, atom dan molekul yang tereksitasi, photon dan partikel netral memiiki energi tinggi yang disebut plasma yang membantu dalam reaksi perengkahan. Radikal bebas yang terbentuk saling bergabung satu sama lain membentuk senyawa FAME dan senyawa lain yang lebih stabil. Oleh karena produk yang dihasilkan mempunyai jenis senyawa yang bermacammacam dan tidak terdapat gliserol maka mekanisme reaksi yang terjadi tidak mengikuti 
Tabel 2. Identifikasi dan Komposisi Produk Biodiesel (FAME) dengan GC-MS

\begin{tabular}{|c|c|c|c|}
\hline Peak & Komponen & Senyawa & $\begin{array}{c}\text { Komposisi } \\
(\%)\end{array}$ \\
\hline 1 & $\mathrm{C}_{12} \mathrm{H}_{12}$ & 1-Heptyne & 7,17 \\
\hline 2 & $\mathrm{C}_{17} \mathrm{H}_{34} \mathrm{O}_{2}$ & Pentadecanoic Acid Methyl ester & 22,00 \\
\hline 3 & $\mathrm{C}_{19} \mathrm{H}_{34} \mathrm{O}_{2}$ & $9,12-$ - & 8,06 \\
\hline 4 & $\mathrm{C}_{19} \mathrm{H}_{36} \mathrm{O}_{2}$ & 11-Octadecadienoic Acid Methyl ester & 36,43 \\
\hline 5 & $\mathrm{C}_{17} \mathrm{H}_{34} \mathrm{O}_{2}$ & Pentadecanoic Acid Methyl ester & 7,05 \\
\hline 6 & $\mathrm{C}_{6} \mathrm{H}_{18} \mathrm{O}$ & Isooctanol Methyl ester & 4,91 \\
\hline 7 & $\mathrm{C}_{10} \mathrm{H}_{18} \mathrm{O}_{2}$ & 7-Nonenoic Acid Methyl ester & 2,11 \\
\hline 8 & $\mathrm{C}_{16} \mathrm{H}_{30} \mathrm{O}_{2}$ & 9-Hexadecenoic Acid & 2,53 \\
\hline 9 & $\mathrm{C}_{16} \mathrm{H}_{36} \mathrm{O}$ & Octadecanal & 2,22 \\
\hline 10 & $\mathrm{C}_{18} \mathrm{H}_{34} \mathrm{O}$ & 9-Octadecenal & 7,51 \\
\hline
\end{tabular}

mekanisme transesterifikasi melainkan mekanisme reaksi perengkahan.

Proses elektro-katalisis dari reaktan metanol dan minyak menghasilkan senyawa-senyawa seperti metil ester (FAME/biodiesel), aldehid, alkuna, alkohol, ester, dan asam karboksilat (tersaji di Gambar 6 dan Tabel 2). Berkaitan dengan spesifikasi biodiesel yang dihasilkan, karakterisasi terhadap produk biodiesel dilakukan untuk parameter-parameter seperti: densitas, viskositas, angka asam, angka setana, bilangan iod, angka penyabunan, dan kalor bakar. Karakterisasi sifat fisik biodiesel hasil percobaan dan dibandingkan dengan SNI disajikan di Tabel 3.

Tabel 3. Perbandingan Karakterisasi Biodiesel

\begin{tabular}{|l|c|l|}
\hline Karakteristik & $\begin{array}{l}\text { Hasil } \\
\text { Percobaan }\end{array}$ & \multicolumn{1}{|c|}{ SNI } \\
\hline Densitas (g/ml) & 0,90 & $0,85-0,89$ \\
\hline $\begin{array}{l}\text { Viscositas Kinematis } \\
\text { (cSt) }\end{array}$ & 20,0 & $2,3-6,0$ \\
\hline Angka Asam & 0,671 & Maks 0,8 \\
\hline Angka Setana & 51,73 & Min 51 \\
\hline Bilangan Iod & 97,65 & Maks 115 \\
\hline Angka Penyabunan & 199,44 & 261,26 \\
Kalor Bakar (kal/g) & 9105 & - \\
\hline
\end{tabular}

Dari data di Tabel 3 tersebut, angka asam, angka setana, bilangan iod, dan angka penyabunan memenuhi standar biodiesel SNI, sedangkan densitas dan viskositas tidak memenuhi standar SNI untuk biodiesel. Hal ini dikarenakan metil ester (biodiesel) yang terkandung dalam produk hanya sekitar 75\%, sedangkan yang lainnya adalah senyawa-senyawa lain sehingga mengakibatkan densitas dan viskositasnya lebih besar dan tidak memenuhi standar SNI. Nilai kalor bakar biodiesel yang dihasilkan adalah sebesar $9105 \mathrm{kal} / \mathrm{g}$.

\section{Kesimpulan}

Dari hasil-hasil penelitian ini dapat disimpulkan bahwa semakin besar tegangan listrik yang digunakan maka semakin besar yield produk yang dihasilkan. Sementara itu, semakin lebar jarak antar elektroda menyebabkan yield produk yang dihasilkan semakin sedikit. Perbandingan mol metanol/minyak yang se- makin besar menyebabkan yield produk yang dihasilkan semakin kecil. Waktu reaksi yang semakin lama menyebabkan yield produk yang dihasilkan semakin besar. Dari penelitian ini, yield produk terbesar adalah $89,8 \%$ yang didapatkan pada variabel perbandingan mol metanol/minyak $3: 1$, dengan tega-ngan listrik sebesar $10 \mathrm{kV}$, jarak antar elektroda sebesar $1,5 \mathrm{~cm}$ dan waktu reaksi selama 30 detik. Ka-rakterisasi biodiesel menunjukkan bahwa senyawa yang terdeteksi di dalam produk melalui analisa GC-MS antara lain: FAME, aldehid, alkuna, alkohol, ester, dan asam karboksilat. Nilai angka asam, angka setana, bilangan iodin, dan angka penyabunan telah memenuhi standar biodiesel SNI namun densitas dan viskositas belum memenuhi standar SNI untuk biodiesel.

\section{Ucapan Terimakasih}

Ucapan terima kasih disampaikan kepada Grand Penelitian Hibah Kompetensi (DitLitabmas DIKTI) sebagai sumber pendanaan penelitian ini. Terimakasih juga disampaikan kepada Beasiswa Unggulan Fastrack DIKTI 2012 atas pendanaan studi S2 ini. Ucapkan terimakasih juga kami sampaikan kepada Wisnu Wijayanto (Teknisi Laboratorium Pabrikasi dan Permesinan Teknik Kimia Fakultas Teknik Universitas Diponegoro) yang membantu dalam terselesaikannya penelitian ini. Terimakasih juga kami sampaikan kepada Laboratorium Rekayasa Proses Teknik Kimia Universitas Diponegoro sebagai tempat penelitian ini berlangsung.

\section{Daftar Pustaka}

1. Azcan, N., \& Yilmaz, O. (2012). Microwave Irradiation Application in Biodiesel Production from Promising Biodiesel Feedstock: Microalgae (Chlorella protothecoides). World Congress on Engineering and Computer Science 2012. II: 1-6.

2. Babajide, O., Petrik, L., Amigun, B., \& Ameer, F. (2010). Low-Cost Feedstock Conversion to Biodiesel via Ultrasound Technology. Energies. 3:1691-1703.

3. Caldwell, T.A., Le, H., Lobban, L.L., Mallinson, R.G. (2001). In: Spivey JJ, Iglesia E, Fleisch TH, editors. Studies in Surface Science and Catalysis, 136. Amsterdam: Elsevier: 265-270. 
4. Eliasson, B., Kogelschatz, U (1991), Modeling and Applications of Silent Discharges Plasmas. IEEE Transaction Plasma Science. 19: 309-323.

5. Gude, V., Patil, P., Martinez-Guerra, E., Deng, S., \& Nirmalakhandan, N. (2013). Microwave energy potential for biodiesel production: a review. Sustainable Chemical Processes. 1: 1-31.

6. Istadi, (2006). Aplikasi Teknologi Hibrid Katalisis - Plasma Dalam Pengembangan Reaktor Kimia Masa Depan. Bulletin of Chemical Reaction Engineering \& Catalysis. 2: 15-20.

7. Istadi, \& Amin, N.A.S. (2006). Co-generation of synthesis gas and $\mathrm{C} 2+$ hydrocarbons from methane and carbon dioxide in a hybrid catalytic-plasma reactor: A review. Fuel. 85: 577-592.

8. Jahanmiri, a., Rahimpour, M. R., Mohamadzadeh Shirazi, M., Hooshmand, N., \& Taghvaei, H. (2012). Naphtha cracking through a pulsed DBD plasma reactor: Effect of applied voltage, pulse repetition frequency and electrode material. Chemical Engineering Journal. 191: 416-425.

9. Joelianingsih, Nabetani, H., Sagara, Y., Tambunan, A. H., \& Abdullah, K. (2012). A continuousflow bubble column reactor for biodiesel production by non-catalytic transesterification. Fuel. 96 : 595-599.

10.Juan, J. C., Kartika, D. A., Wu, T. Y., \& Hin, T.Y. Y. (2011). Biodiesel production from Jatropha oil by catalytic and non-catalytic approaches: an overview. Bioresource technology. 102: 452-460.

11.Lawson, J. A., \& Baosman, A. A. (2010a). Metthod Of Elctro-Catalytic Reaction To Produce Mono Alkyl Ester For Renewable Biodiesel. United states Patent No. 7,722,755 B2.

12.Lawson, J. A., \& Baosman, A. A. (2010b). Chemical Synthesis Methods Using ElectroCatalysis. United states Patent No. 7,695,534 B2.

13.Lindner, P. J., \& Besser, R. S. (2012). Hydrogen production by methanol reforming in a nonthermal atmospheric pressure microplasma reactor. International Journal of Hydrogen Energy. 37: 13338-13349.

14.Moscosa-Santillan, M., Vincent, A., Santirso, E., \& Amouroux, J. (2008). Design of a DBD wirecylinder reactor for NOx emission control: experimental and modelling approach. Journal of Cleaner Production. 16: 198-207.

15.Ndong, a. C. A., Zouzou, N., Benard, N., \& Moreau, E. (2013). Geometrical optimization of a surface DBD powered by a nanosecond pulsed high voltage. Journal of Electrostatics. 71: 246253.

16.Rahimpour, M. R., Jahanmiri, a., Mohamadzadeh Shirazi, M., Hooshmand, N., \& Taghvaei, H. (2013). Combination of non-thermal plasma and heterogeneous catalysis for methane and hexadecane co-cracking: Effect of voltage and catalyst configuration. Chemical Engineering Journal. 219: 245-253.
17.Taghvaei, H., Shirazi, M. M., Hooshmand, N., Rahimpour, M. R., \& Jahanmiri, A. (2012). Experimental investigation of hydrogen production through heavy naphtha cracking in pulsed DBD reactor. Applied Energy. 98: 3-10. 
